Volume 10, Nomer 02, 2020

\title{
Pendidikan Kesehatan Meningkatkan Tingkat Pengetahuan dan Sikap Ibu dalam Merawat Balita dengan ISPA
}

\author{
Dewi Purnama Sari ${ }^{1}$, Diah Ratnawati ${ }^{2}$ \\ Fakultas Ilmu Kesehatan, Universitas Pembangunan Nasional Veteran Jakarta \\ Email : dewipurnamasari@upnvj.ac.id ${ }^{1}$, ratnawatidiah@yahoo.co.id ${ }^{2}$
}

\begin{abstract}
Abstrak
Pendahuluan : Pendidikan kesehatan merupakan serangkaian mempengaruhi seseorang demi terciptanya perilaku hidup sehat. Penyuluhan kesehatan masyarakat merupakan suatu kegiatan pendidikan yang dilakukan dengan cara menyebarkan pesan, kepada msayarakat sehingga masyarakat sadar, tahu, mengerti, mau dan dapat melakukan satu tindakan yang behubungan dengan kesehatan.

Tujuan : Tujuan dari penelitian ini adalah untuk mengetahui pengaruh pendidikan kesehatan terhadap tingkat pengetahuan dan sikap pada ibu balita dalam merawat anak dengan infeksi saluran pernafasan akut di Posyandu Kelurahan Limo.

Metode: Metode penelitian yang digunakan adalah quasi eksperimen dan analisa data menggunakan menggunakan uji t-test dependent. Pengambilan sampel dilakukan dengan cara purposive sampling pada ibu yang memiliki balita usia satu sampai lima tahun di Posyandu Kelurahan Limo sebanyak 53 orang.

Hasil: Hasil penelitian menunjukan ada pengaruh antara pendidikan kesehatan terhadap tingkat pengetahuan dan sikap ibu dalam dalam merawat balita dengan ISPA.

Kesimpulan: Hasil penelitian ini menunjukan bahwa pendidikan kesehatan memiliki pengaruh yang signifikan terhadap pengetahuan dan sikap pada ibu balita tentang ISPA di Posyandu Kelurahan Limo.
\end{abstract}

Kata Kunci : Infeksi Saluran Pernapasan Akut pada Balita, Pendidikan Kesehatan, Pengetahuan, Sikap.

\section{Pendahuluan}

Anak usia di bawah lima tahun atau disingkat balita adalah anak yang memiliki usia diatas satu tahun, lebih sering diartikan sebagai usia anak kurang dari lima tahun. ${ }^{1}$ Peraturan Menteri Kesehatan RI No. 25 Tahun 2014 Anak balita adalah anak yang berumur 12 bulan hingga 59 bulan $^{2}$. Masa balita memiliki rentang ketika anak tersebut mulai berjalan hingga mampu berlari, yaitu ketika usia anak tersebut antara $12-36$ bulan. ${ }^{3}$ Jadi

\begin{abstract}
Introduction : Health education is a series of influencing someone to create healthy living behavior. Public health counseling is an educational activity carried out by disseminating messages, to the community so that the community is aware, knows, understands, wants, and can take actions that are related to health.

Purpose :The purpose of this report to determine the effect of health education on the level of knowledge and attitudes in mothers of children under five in caring for children with Acute Respiratory Infection at Integrated Health Center Kelurahan Limo.

Method: This research method uses quasiexperiment and data analysis using a t-test dependent test. The sample was 53 respondents who had a child aged one to five years at Integrated Health Center Kelurahan Limo with a purposive sampling method.

Results: The results showed that there was a significant effect between health education on the level of knowled and the attitude of mother in caring for children with Acute Respiratory Infection Conclusion: This shows that health education has a significant influence on the knowledge and attitude of a mother with a toddler about Acute Respiratory Infection at Integrated Health Center Kelurahan Limo.
\end{abstract}

Keywords: Acute Respiratory Infection in Toddlers, Health Education, Knowledge,Attitudes

dapat disimpulkan bahwa balita merupakan anak usia 1 sampai 5 tahun dan belum bisa melakukan akivitas sendiri. Masa balita memiliki tahapan yang sangat penting dalam proses pertumbuhan dan perkembangan.

Balita memiliki daya tahan tubuh yang masih sangat rentan sehingga rentan mengalami masalah kesehatan. Penyakit yang paling banyak diderita balita adalah Infeksi Saluran Pernafasan Akut (ISPA). Infeksi Saluran 
Pernafasan Atas (ISPA) adalah infeksi akut yang terjadi pada bagian saluran napas mulai dari hidung sampai alveoli termasuk organ yang berhubungan (sinus, rongga telinga tengah, Pleura $)^{4}$. Penyebab dari penyakit Infeksi Saluran Pernapasan Akut (ISPA) virus dan bakteri $^{5}$. Data juga berbicara bahwa sebanyak $50 \%$ penyakit menyerang anak balita merupakan ISPA. Penyakit ISPA pada anak sebagian besar menyerang saluran pernafasan atas, tetapi sekitar 5\% menyerang saluran pernapasan bawah terutama pneumiona ${ }^{6}$. Penyakit ISPA dapat menjadi penyebab tingginya angka penderita dan angka kematian pada penderita.

World Lung Fondation mengemukakan bahwa penyakit ISPA menjadi penyebab pertama kesakitan serta kematian akibat dari penyakit menular di dunia ${ }^{7}$. Angka mortalitas ISPA di dunia mencapai 4,25 juta pertahun dan kelompok paling beresiko adalah pada balita ${ }^{7}$. Menurut WHO dalam terjemahan bebas infeksi pernafasan bawah merupakan penyakit menular yang paling mematikan, menyebabkan 3,0 juta kematian di seluruh dunia pada $2016^{8}$. Data Riskesdas, 2018 dapat diketahui provinsi dengan ISPA tertinggi di Indonesia antara lain Provinsi Nusa Tenggara Timur (18,6\%), Provinsi Banten $(17,7 \%)$, Provinsi Jawa Timur (17,2\%), Provinsi Bengkulu (16,4\%), Provinsi Kalimantan Tengah $(15,1 \%)$, dan Provinsi Jawa Barat berada diurutan keenam $(14,7 \%){ }^{9}$. Data Laporan Rutin Subdit ISPA Tahun 2017, diperoleh hasil bahwa kejadian ISPA (per 1000 balita) di Indonesia sebesar 20,54\% ${ }^{10}$. Penyakit ISPA dapat menyerang berbagai kalangan usia.

Penyakit ISPA paling tinggi terjadi pada usia balita sebesar $25,8 \%$ dan terjadi pada kelompok umur 1-4 tahun dan tidak ada perbedaan antara pria maupun wanita ${ }^{5}$. Profil Kesehatan Kota Depok tahun 2016 diketahui bahwa penderita penyakit rawat jalan di puskesmas menurut kelompok umur 1 sampai 4 tahun, penyakit ISPA menduduki posisi teratas $(28,24 \%)$, Nasofaringitis akut $(27,50 \%)$ dan diposisi ketiga Faringitis Akut $(8,04 \%){ }^{11}$. Balita mudah terserang ISPA karena sistem imun yang rendah dan adanya faktor penentu ISPA menyerang balita.
Penyakit ISPA dapat menyerang balita karena adanya faktor dari dalam diri (intrinsik) sarta dari luar (ekstrinsik). Faktor instrinstik penyebab ISPA meliputi jenis kelamin, umur, status gizi, ASI ekslusif, imunisasi. Faktor dari luar penyebab ISPA meliputi kondisi fisik lingkungan, kepadatan tempat tinggal, polusi udara, bentuk/tipe rumah, ventilasi udara, asap rokok, pemakaian bahan bakar. Terdapat faktor lain dari faktor ekstrinsik yaitu perilaku ibu, baik pengetahuan maupun sikap ibu ${ }^{12,}{ }^{13}$. Ibu merupakan sosok yang tepat untuk mencegah ISPA pada balita.

Peran seorang ibu merawat balita sakit sangatlah penting karena kebutuhan dasar balita masih bergantung dengan ibu. Ibu berperan sebagai pendidik, pelindung anak dan pemberi perawatan pada keluarga yang sakit terutama pada balita. Kejadian ISPA berulang pada balita dapat dipengarui oleh salah satu faktor yaitu tingkat pengetahuan ibu terhadap penyakit ISPA $^{13}$. Pengetahuan yang dimiliki, seorang ibu dapat membantu mencegah masalah kejadian ISPA pada balita. Ibu akan lebih mewaspadai dan melindungi anak dari ISPA karena pengetahuan yang dimilikinya ${ }^{13}$.

Tinggi rendahnya tingkat pengetahuan mengenai penyakit yang dimiliki orang tua mempunyai pengaruh terhadap sikap orang tua. Pengetahuan yang meningkat diharapkan dapat mengubah sikap orang tua dalam mengatasi penyakit ISPA. Sikap yang perlu diterapkan orang tua antara lain sikap terhadap sakit dan penyakit, yaitu bagaimana tanggapan terhadap tanda dan gejala, penyakit, penyebab, cara penularan, penanganan dan lainnya ${ }^{14}$. Kenyataannya masih kurangnya tingkat pengetahuan ibu terhadap penyakit. Salah satu upaya untuk meningkatkan pengetahuan dan sikap orang tua dengan diadakannya pendidikan kesehatan. Pendidikan kesehatan sangat penting dan merupakan suatu bagian peran dari perawat profesional dalam upaya promosi kesehatan dan pencegahan penyakit secara preventif $f^{15,16}$.

Kurangnya pengetahuan dan informasi terkait masalah kesehatan atau mengenai suatu penyakit mengakibatkan terjadinya perilaku menyimpang baik dalam pengetahuan mengenai penyakit, perawatan, pemeliharaan maupun dalam pencegahan. Pemahaman dan pengetahuan terhadap masalah atau penyakit diperlukan dalam perawatan dan pemeliharaan 
kesehatan, selain hal tersebut dengan pemahaman dan pengetahuan akan kesehatan dapat mengubah sikap menjadi lebih baik

Melalui penelitian ini diharapkan dapat mengetahui gambaran pengetahuan dan sikap ibu balita mengenai ISPA di Posyandu Kelurahan Limo sebelum dan sesudah dilakukan pendidikan kesehatan. Serta mengetahui pengaruh antara pendidikan kesehatan dengan tingkat pengetahuan dan sikap orang tua tentang ISPA pada balita.

\section{Metode}

Penelitian ini menggunakan jenis penelitian kuantitatif dengan desain penelitian Quasi-Eksperimental dengan menggunakan one group pre test - post test yang mana variabel bebas yaitu pendidikan kesehatan sedangkan variabel terikat yaitu tingkat pengetahuan dan sikap ibu terhadap ISPA diukur dan diambil pada satu waktu.

Populasi sampel merupakan bagian dari populasi target. Populasi target penelitian ini adalah ibu dengan balita di Kelurahan Limo dan populasi sampel dalam penelitian ini adalah ibu dengan balita di Posyandu Mawar 2, Flamboyan, dan Melati 2 Kelurahan Limo sebanyak 482 orang, kemudian jumlah sampel di hitung menggunakan rumus beda mean didapatkan sampel sebanyak 53 responden. Metode pengambilan sampel menggunakan simple random sampling dalam memilih 3 Posyandu di Kelurahan Limo dan menggunakan metode purposive sampling dalam pengambilan sampel disetiap posyandu ketika sampel yang diambil disesuaikan dengan kriteria peneliti dalam penelitian. Analisa data menggunakan uji paired t-test.

\section{Hasil}

\section{Karakteristik subjek}

Distribusi Frekuensi berdasaarkan Usia, pendidikan, pekerjaan dalam penelitian ini memiliki karakteristik sebagai berikut:

Tabel 1. Karakteristik subjek berdasarkan usia, pendidikan, dan pekerjaan $(\mathrm{n}=53)$

\begin{tabular}{llc}
\hline \multicolumn{1}{c}{ Karakteristik } & \multicolumn{2}{c}{ Subjek } \\
\hline Usia & $\mathrm{N}=53$ & $\%$ \\
$20-25$ & 6 & 11.3 \\
$26-35$ & 38 & 71.7
\end{tabular}

Submite : 03/05/20

Review : $15 / 5 / 20$

\begin{tabular}{lll}
\hline $36-45$ & 9 & 17.0 \\
Pendidikan & & \\
SD & 8 & 15.1 \\
SMP & 10 & 18.9 \\
SMA & 32 & 60.4 \\
Perguruan & 3 & 5.7 \\
tinggi/Akademi & & \\
& & \\
Pekerjaan & & \\
Tidak bekerja & 45 & 84.9 \\
Bekerja & 8 & 15.1 \\
\hline
\end{tabular}

Berdasarkan tabel 1 menunjukkan bahwa sebagian besar berumur antara 26 - 35 tahun sebanyak 38 orang $(71.7 \%)$. Karakteristik berdasarkan pendidikan dibagi menjadi 4 yaitu SD,SMP,SMA dan Perguruan Tinggi/Akademi. Penelitian ini didominasi dengan ibu berpendidikan SMA sebanyak 32 responden $(60.4 \%)$. Karakteristik berdasarkan pekerjaan sebanyak 45 responden $(84.9 \%)$ tidak bekerja, dan sebanyak 8 responden (15.1\%) bekerja, sebagian besar ibu tidak bekerja atau sebagai ibu rumah tangga dan hanya mengurus keluarga.

Tabel 2. Distribusi Rata-Rata Pengetahuan dan Sikap Responden terhadap Penyakit ISPA pada Balita di Posyandu Kelurahan Limo ( $\mathrm{n}=53)$

\begin{tabular}{lllll}
\hline Variabel & Mean & SD & Min & Max \\
\hline $\begin{array}{l}\text { Pengetahuan } \\
\text { Pre-test }\end{array}$ & 13.13 & 2.038 & 8 & 17 \\
$\begin{array}{l}\text { Post-test } \\
\text { Sikap }\end{array}$ & 14.15 & 1.680 & 10 & 17 \\
pre-test & 48.21 & 3,800 & 41 & 57 \\
post-test & 49.15 & 4,249 & 40 & 57 \\
\hline
\end{tabular}

Berdasarkan tabel 2 diatas, diperoleh hasil bahwa terdapat peningkatan pengetahuan dilihat dari nilai rata-rata sebanyak 13.13 menjadi 14.15 dan dengan meningkatnya nilai minimal menjadi 8 namun tidak ada perubahan pada nilai tertinggi sebelum dan sesudah dilakukan pendidikan kesehatan. Peningakatan sikap dibuktikan dengan nilai rata-rata sebelum dan sesudah dilakukan pendidikan kesehatan yaitu dari 48.21 menjadi 49.15. Terjadi penurunan pada nilai minimun dari 41 menjadi 40 , pada nilai tertinggi tidak ada peningkatan 
dan penurunan yaitu sebesar 57 sebelum dan sesudah dilakukan pendidikan kesehatan.

Tabel 3. Analisis Perbedaan Rata-rata Pengetahuan dan Sikap Ibu Terhadap ISPA Pada balita di Posyandu Kelurahan Limo $(\mathrm{n}=53)$

\begin{tabular}{lcccc}
\hline \multicolumn{1}{c}{ Variabel } & Mean & SD & $\begin{array}{c}\text { Mean } \\
\text { Differen } \\
\text { ce }\end{array}$ & $\begin{array}{c}\boldsymbol{P} \\
\text { Value }\end{array}$ \\
\cline { 2 - 3 } $\begin{array}{l}\text { Pengetahuan } \\
\text { Pretest }\end{array}$ & 13.13 & & & \\
$\begin{array}{l}\text { Postest } \\
\text { Sikap }\end{array}$ & 14.15 & 1.770 & -1.019 & 0.000 \\
$\begin{array}{l}\text { Pretest } \\
\text { Postest }\end{array}$ & 48.21 & & & \\
\hline
\end{tabular}

Berdasarkan tabel 3 diatas, hasil analisis pengaruh pendidikan kesehatan terhadap pengetahuan ibu mengenai ISPA pada balita di Posyandu Kelurahan Limo menunjukan perbedaan mean yaitu sebesar -1.019 dengan standar deviasi sebesar 1.770. Hasil uji statistik didapatkan nilai $p$-Value $=0,000<0,05$, sehingga Ho ditolak. Hasil analisis pengaruh pendidikan kesehatan terhadap sikap ibu menunjukan adanya perbedaan mean sebesar 0.943 dengan SD sebesar 3.128. Hasil uji statistik didapatkan nilai $p$-Value $=0,033<0,05$, sehingga Ho ditolak. Hasil ini menunjukkan bahwa ada hubungan yang signifikan antara pendidikan kesehatan terhadap pengetahuan dan sikap ibu mengenai ISPA pada balita di Posyandu Kelurahan Limo.

\section{Pembahasan \\ Usia}

Berdasarkan hasil penelitian ini diketahui bahwa rata-rata usia dalam penelitian ini adalah 31 tahun yang merupakan masuk kedalam fase dewasa awal 26 - 35 tahun menurut Depkes, 2009. Usia dewasa merupakan masa dimana seseorang dianggap telah matur, baik secara fisiologis, psikologis, dan kognitif ${ }^{3}$. Usia 18-30 tahun (dewasa awal) merupakan usia yang tepat dalam menganalisa dan menerima sesuatu informasi. Secara kognitif, kebiasaan berpikir rasional meningkat pada usia dewasa awal dan tengah $^{3}$.

Jadi dapat disimpulkan bahwa umur responden adalah merupakan termasuk usia dewasa awal, sehingga pada usia tersebut masih mudah untuk memerima informasi dengan baik dibandingkan usia lebih dari kelompok usia lebih tua, dan keinginan untuk memperoleh informasi untuk menambah pengetahuan masih tinggi sehingga dapat menjadi pengaruh pada saat dilakukannya pendidikan kesehatan.

\section{Pendidikan}

Penelitian ini didominasi dengan ibu berpendidikan SMA sebanyak 32 responden $(60.4 \%)$ yang artinya bahwa mayoritas pendidikan responden menengah. Salah satu faktor yang mempengaruhi pengetahuan adalah tingkat pendidikan, dimana tingkat pendidikan yang lebih tinggi mempengaruhi persepsi seseorang untuk mengambil keputusan dan bertindak ${ }^{17}$. Semakin tinggi tingkat pendidikan yang dimiliki ibu, semakin baik pula pencegahan pada penyakit pneumonia dan semakin rendah pendidikan yang dimiliki ibu maka semakin buruk pencegahan penyakit pneumonia ${ }^{18}$. Berbanding terbalik dengan penelitian yang menyatakan bahwa tidak ada hubungan antara tingkat pendidikan ibu dengan kemampuan ibu merawat balita ISPA di Puskesmas Bahu responden dapat dilihat dari responden dengan tingkat pendidikan SMP memiliki perawatan ISPA yang baik dibandingkan dengan responden yang berpendidikan tinggi ${ }^{19}$.

Pendidikan responden bisa berpengaruh terhadap pengetahuan seseorang namun bukan berarti tidak jika berpendidikan rendah maka pengetahuan menjadi rendah pula, selain itu ibu yang memperhatikan kondisi kesehatan anak akan lebih tahu mengenai tanda gejala awal penyakit sehingga dapat melakukan tindakan yang benar. Walaupun responden dalan penelitian ini terbanyak adalah berpendidikan SMA dan paling sedikit adalah perguruan tinggi namun untuk pengetahuan tentang ISPA merata atau tidak jauh berbeda dengan responden berpendidikan tinggi. Pengetahuan dapat meningkat dan mempengaruhi seseorang jika orang tersebut sering berinteraksi dan mendapat informasi dari luar seperti dari teman, tetangga maupun media.

\section{Pekerjaan}

Hasil analisis menunjukan sebagian besar ibu tidak bekerja atau sebagai ibu rumah 
tangga dan hanya mengurus keluarga. Peneliti lebih banyak bertemu dengan ibu balita diposyandu adalah sebagai ibu rumah tangga, karena ibu rumah tangga memiliki waktu yang lebih banyak untuk mengurus anaknya dan membawa anaknya ke posyandu. Ibu rumah tangga berperan untuk mengurus rumah tangga, sebagai pengasuh dan pendidik anak-anaknya, pelindung dan salah satu kelompok sosial serta sebagai anggota masyarakat dan lingkungan ${ }^{20}$. Pekerjaan mempengaruhi pengetahuan, orang yang sering berinteraksi dengan orang lain akan lebih banyak terpapar informasi atau pengetahuan dibandingkan dengan orang tanpa ada interaksi dengan orang lain ${ }^{17}$. Seorang ibu rumah tangga lebih sering berinteraksi dengan keluarga atau dengan ibu lain ketika sedang menjaga anaknya bermain diluar sehingga dapat bertukar informasi dan pengalaman satu sama lain mengenai informasi kesehatan. Selain itu dapat melalui televisi, majalah ataupun dengan mengakses internet yang mudah sehingga dapat meningkatakan pengetahuan untuk mencegah penyakit, memelihara kesehatan dan meningkatkan status kesehatan keluarga .

\section{Perbedaan Rata-rata Pengetahuan dan Sikap Ibu Terhadap ISPA Pada Balita}

Hasil penelitian ini menunjukkan bahwa ada hubungan yang signifikan antara pendidikan kesehatan terhadap pengetahuan ibu mengenai ISPA pada balita di Posyandu Kelurahan Limo. Penelitian ini didukung oleh penelitian yang dilakukan Fatmawati (2017) menunjukkan ada pengaruh yang signifikan antara pengetahuan responden sebelum dengan setelah diberikan pendidikan kesehatan. Pendidikan kesehatan dilakukan dengan tujuan untuk meningkatkan pengetahuan, sikap dan tindakan individu atau masyarakat sehingga sesuai dengan norma-norma hidup sehat, pendidikan akan berpengaruh padaperilaku kesehatan, selanjutnya perilaku kesehatan akan berpengaruh pada meningkatnya indikator kesehatan masyarakat (outcome) pendidikan kesehatan ${ }^{17}$. Tujuan pendidikan kesehatan adalah untuk mengubah perilaku seseorang atau masyarakat dari perilaku tidak baik menjadi perilaku yang lebih baik.

Penelitian Novrianda, Lucida, \& Soumariris (2017) didapatkan hasil bahwa pengetahuan tentang penyakit ISPA pada balita oleh responden baik di Puskesmas Padang Pasir dan Pauh sebelum dan setelah dilakukan pendidikan kesehatan berdasarkan hasil analisis statistik menunjukkan terdapat perbedaan yang bermakna $^{21}$

Pemilihan dan penggunaan media merupakan salah satu komponen yang penting. Pengetahuan paling banyak disalurkan oleh organ penglihatan / mata. Oleh sebab itu, dalam aplikasi pembuatan media disarankan lebih banyak menggunakan alat-alat visual ataupun audiovisual karena akan mempermudah cara penyampaian dan penerimaan informasi oleh masyarakat ${ }^{22,24}$. Peningkatan pengetahuan keluarga setelah diberikan perlakuan merupakan akibat dari pemberian pendidikan kesehatan dengan media audiovisual. Dengan demikian media audiovisual sebagai media pendidikan kesehatan efektif digunakan untuk meningkatkan pengetahuan keluarga menjadi lebih baik.

Peneliti menyimpulkan bahwa hasil penelitian ini menunjukkan bahwa ada hubungan yang signifikan antara pendidikan kesehatan terhadap pengetahuan ibu mengenai ISPA pada balita di Posyandu Kelurahan Limo. Hasil penelitian ini sesuai dengan teori bahwa pengetahuan ibu dapat dipengarui oleh pendidikan kesehatan yang dilakukan yaitu dari uji statistik menunjukan perbedaan rata-rata sebesar -1.019 dengan standar deviasi sebesar 1.770. Hasil uji statistik didapatkan nilai $p$ Value $=0,000<0,05$, sehingga menunjukkan bahwa ada hubungan yang signifikan antara pendidikan kesehatan terhadap pengetahuan ibu mengenai ISPA pada balita di Posyandu Kelurahan Limo.

Ibu dapat memperoleh informasi lebih mengenai ISPA pengertian, tanda gejala, penangana, pengobatan dan pencegahannya dengan adanya pendidikan kesehatan. Pendidikan kesehatan memiliki tujuan untuk mengubah pengetahuan, sikap dan tindakan sehingga sesuai norma-norma untuk hidup sehat, pendidikan akan memppengaruhi perilaku kesehatan, selanjutnya perilaku kesehatan mempengaruhi meningkatnya indicator kesehatan masyarakat (outcome) ${ }^{17}$.

Pengaruh pendidikan kesehatan terhadap sikap ibu mengenai ISPA pada balita di Posyandu Kelurahan Limo didiperoleh bahwa 
dari hasil analisis menunjukan perbedaan mean sebesar -0.943 dengan SD sebesar 3.128. Hasil uji statistik didapatkan nilai $p$-Value $=0,033$ $<0,05$, sehingga menunjukkan bahwa ada hubungan yang signifikan antara pendidikan kesehatan terhadap sikap ibu mengenai ISPA pada balita di Posyandu Kelurahan Limo.

Pengetahuan atau kognitif merupakan domain yang sangat penting dalam membentuk tindakan seseorang (over behavior). Sikap yang merpakan respon yang masih tertutup seseorang menunjukan kesesuaian reaksi terhadap stimulus tertentu yang merupakan suatu reaksi emosional terhadap stimulus sosial ${ }^{20,23}$.

Penelitian ini juga didukung dengan teori model Lawrence Green, bahwa terdapat 3 faktor yang mempengaruhi perilaku kesehatan yaitu faktor predisposisi, faktor pendukung dan faktor pendorong ${ }^{17}$. Faktor predisposisi (predisposing factor) didalamnya termasuk pengetahuan, sikap, kepercayaan, keyakinan dan nilai- nilai. Pengetahuan dan sikap seseorang terhadap apa yang akan dilakukan merupakan salah satu faktor yang dapat mempermudah atau mempredisposisi terjadinya perilaku pada diri seseorang atau masyarakat. Pengetahuan yang dimiliki ibu tentang ISPA maka dia akan dapat mengambil sikap mengenai apa yang harus dilakukan untuk mencegah penyakit tersebut ${ }^{25}$. Selain itu pengetahuan juga sangat mempengaruhi tingkat pengetahun ${ }^{27}$ dalam hal ini adalah pengetahuan Ibu dalam penelitian yang dilakukan PkM Cianur. $^{26}$ Allport mengemukakan tiga komponen pembentuk sikap yaitu kepercayaan (keyakinan), ide dan konsep terhadap suatu objek, kehidupan emosional atau evaluasi terhadap suatu objek, dan kecenderungan untuk bertindak (tend to behave) yang akan membentuk sikap yang utuh (total attitude). Pengetahuan, pikiran, keyakinan, dan emosi memegang peran penting dalam menentukan sikap yang utuh ${ }^{17}$.

Peneliti menyimpulkan bahwa dengan meningkatnya pengetahuan iibu maka meningkat pula sikap yang dimiliki ibu terhadap penyakit. Hasil olah data menujukan adanya peingkatan rata-rata responden. Ketika dilakukan pendidikan kesehatan, responden yang menyimak dan memperhatikan dengan baik maka pengetahunapun akan bertambah. Meningkatnya pengetahuan seseorang diharapkan dapat merubah sikap menjadi lebih baik sehingga dapat merubahan perilaku seseorang menjadi baik pula, khususnya dalam kesehatan. Seorang ibu yang memiliki perilaku baik maka dapat mengurus keluarganya dengan baik.

\section{Kesimpulan}

Berdasarkan hasil analisa yang telah dilakukan dapat disimpulkan bahwa dari karakteristik responden di Posyandu Kelurahan Limo sebagian besar usia responden (26-35 tahun) Berdasarkan tingkat pendidikan sebagian besar berpendidikan akhir adalah SMA. Berdasarkan pekerjaan didapatkan hasil paling banyak yang tidak bekerja atau hanya sebagai ibu rumah tangga. Pengetahuan ibu mengenai penyakit ISPA pada balita di Posyandu Kelurahan Limo yaitu mengalami peningkatan rata-rata skor pengetahuan Pre test dan rata - rata skor pengetahuan Post test dan sikap ibu mengenai penyakit ISPA pada balita di Posyandu Kelurahan Limo mengalami peningkatan rata-rata skor Pre test dan dari rata - rata skor sikap Post test. Pengaruh secara signifikan terjadi antara pendidikan kesehatan terhadap pengetahuan dan sikap ibu dalam dalam merawat balita dengan ISPA balita mengenai ISPA di Posyandu Kelurahan Limo.

\section{Daftar Pustaka}

1. Pusat Data dan Informasi Kementerian Kesehatan. Infodatin Kementerian Kesehatan RI Situasi Kesehatan Anak Balita di Indonesia [Internet]. 2015. Available from: file:///C:/Users/acer/Downloads/infodatinanak-balita.pdf

2. KEMENKES. Peraturan Mentri Kesehatan Republik Indonesia Tentang Upaya Kesehatan Anak. Jakarta: Kementrian Kesehatan Republik Indonesia; 2014. 561565 p.

3. Potter P, Perry A. Potter and Perry's Fundamentals of Nursing. 5th ed. Crisp J, Douglas C, Rebeiro G, Waters D, editors. Australia: Elsevier; 2017.

4. Kesehatan RI K. Profil Kesehatan Indonesia Tahun 2012. Jakarta: Kementrian Kesehatan Republik Indonesia; 2013.

5. Riskesdas. Riset Kesehatan Dasar Kementerian RI. Proceedings, Annu Meet Air Pollut Control Assoc [Internet]. 2013;6. Available from: 
http://www.depkes.go.id/resources/downloa d/general/Hasil Riskesdas 2013.pdf

6. Rahajoe NN, Supriyatno B, Setyanto BD. Buku Aja Respirologi Anak. Pertama. Jakarta: Bada Penerbit Ikatan Dokter Anak Indonesia; 2018.

7. Najmah. Epidemiologi Penyakit Menular. Jakarta: CV. Trans Info Media; 2016.

8. WHO. The top 10 causes of death [Internet]. 2018. Available from: https://www.who.int/news-room/factsheets/detail/the-top-10-causes-of-death

9. Kesehatan RI K. RISKESDAS 2018.pdf. Laporaan Nas RISKESDAS 2018. 2018;

10. Kesehatan RI K. Profil Kesehatan Indonesia 2017. Jakarta: Kementrian Kesehatan Republik Indonesia; 2017.

11. Dinas Kesehatan D. Profil kesehatan kota depok 2016. 2017;(54). Available from: http://www.depkes.go.id/resources/downloa d/profil/PROFIL_KAB_KOTA_2016/3276_ Jabar_Kota_Depok_2016.pdf

12. Dewi CC. Hubungan Kondisi Fisik Lingkungan Rumah Dan Perilaku Orang Tua Dengan Kejadian Ispa Pada Balita Di Wilayah Kerja Puskesmas Kedungmundu Kota Semarang. J Kesehat Masy. 2012;1.

13. Umrahwati, Alfiah A, Nurbaya S. FaktorFaktor Yang Berhubungan Dengan Kejadian ISPA Berulang Pada Balita Di Puskesmas Watampone;2:115-22.

14. Apriningsih. Indikator Perbaikan Kesehatan Lingungan Anak. Hardiyanti EA, editor. Jakarta: Penerbit Buku Kedokteran EGC; 2009.

15. Fitriani S. Promosi Kesehatan. Yogyakarta: Graha Ilmu; 2011.

16. Fatmawati TY. Pengaruh Pendidikan Kesehatan dengan Media Leaflet Terhadap Pengetahuan Ibu Tentang Penatalaksanaan Ispa pada Balita Di Posyandu. J Ilm Univ Batanghari. 2017;17(3):227-34.

17. Notoatmodjo S. Promosi Kesehatan dan Perilaku Kesehatan. Jakarta: Rineka Cipta; 2012.

18. Azizah M, Fahrurazi, Qoriaty NI. Tingkat Pengetahuan Dan Pendidikan Ibu Balita Dengan Kejadian Penyakit Pneumonia Pada
Balita Di Kelurahan Keraton Kecamatan Martapura Kabupaten Banjar. 2014;1(1).

19. Maramis PA, Ismanto AY, Babakal A. Hubungan Tingkat Pendidikan dan Pengetahuan Ibu Tentang ISPA Dengan Kemampuan Ibu Merawat Balita ISPA pada Balita di Puskesmas Bahu Kota Manado. 2013;1.

20. Efendi F, Makhfudli. Keperawatan Kesehatan Komunitas Teoi dan Praktek dalam Keperawatan. Jakarta: Penerbit Salemba Medika; 2009.

21. Novrianda D, Lucida H, Soumariris I. Perbandingan Efektivitas Pendidikan Kesehatan terhadap Pengetahuan dan Kemampuan Ibu Merawat Balita ISPA di Puskesmas Padang Pasir dan Pauh. J Sains Farm Klin. 2017;1(2):159.

22. Maulana HDJ. Promosi Kesehatan. Jakarta: EGC; 2009.

23. Purnama, Agus. "Edukasi Dapat Meningkatkan Kualitas Hidup Pasien Yang Terdiagnosa Penyakit Jantung Koroner." Jurnal Kesehatan Indonesia 10.2 (2020): 6671

24. Utari W, Novayelinda R. Efektifitas Pendidikan Kesehatan Terhadap Peningkatan Pengetahuan Keluarga Tentang Infeksi Saluran Pernapasan Akut (ISPA). 2011;1-7.

25. Silviana I. Hubungan Pengetahuan Ibu Tentang Penyakit ISPA dengan Perilaku Pencegahan ISPA pada Balita di PHPT Muara Angke Jakarta Utara Tahun 2014. 2014;402-11.

26. Kusumastuti, Istiana. "Hubungan Karakteristik Ibu, Paritas dan Sumber Informasi dengan Pengetahuan Ibu tentang Tanda Bahaya Kehamilan." Jurnal Ilmiah Kebidanan Indonesia 8.03 (2018): 124-132.

27. Wijayanti, Wijayanti, and Budhi Mulyadi. "Pendidikan Kesehatan Menggunakan Booklet Terhadap Pemahaman Pasien Hipertensi Di Puskesmas." Jurnal Ilmiah Ilmu Keperawatan Indonesia 8.01 (2018): 372-739. 